\title{
NEW METHODOLOGY FOR ESTIMATING EVAPOTRANSPIRATION AND UPDATING CROP COEFFICIENT FOR RICE IN EGYPT BY SURFACE RENEWAL METHOD
} \section{Amal Abo El-Magd ${ }^{1}$, Samar M. Attaher ${ }^{1}$, Richard L. Snyder ${ }^{2}$, Hazem} Sayed Mehawed ${ }^{1}$ and Gamal Hasan ${ }^{1}$

\section{ABSTRACT}

Improving irrigation management needs accurate information and tools to estimate accurate crop-water requirements. At the national level, one of the biggest deficiencies in water-use planning is a lack of continues and updated data sets of evapotranspiration and accurate crop coefficient values. The aim of this study is to evaluate locally, the "Surface Renewal (SR)" method, as an energy balance direct method to estimate crop evapotranspiration (ETc), and upgrade crop coefficients $(K c)$ of rice crop in Egypt. SR station was installed in the "agricultural production sector" farm in Moshtouhor, at Kaliobia governorate, in order to collect high resolution field observations of energy balance factors of paddy rice field. The data was used to calculate the actual crop evapotranspiration (ETC) and crop coefficient $(K c)$ of the crop by using the SR method, and comparing the result with the standard values recommended by FAO. The overall RMSE between the ETc-SR and the ETc-FAO was $0.92 \mathrm{~mm} /$ day. The error was at the highest level at the initial-season stage, and slightly decreased to reach to $0.48 \mathrm{~mm} /$ day by the end of the season. The average value of Kc-SR was 1.17, 1.13 and 1.14 at the initial-season, mid-season and late season stages, respectively. The RMSE between the Kc-SR and the Kc-FAO values were 0.17, 0.10 and 0.03 at the initial-season, the mid-season, and the late-season stages, respectively. The combination of the SR procedure and the simplified surface energy balance equation appears being an affordable alternative to be considered for estimating water use in agriculture. In the other hand, the SR method still need several evaluations, calibration work, in order to be used significantly to upgrade the Kc value for the local crop cultivars in Egypt.

Keywords: energy balance, water requirements, on-farm irrigation management

\footnotetext{
${ }^{1}$ Agriculture Engineering Research Institute (AEnRI), Agricultural Research Center (ARC) Cairo, Egypt.

${ }^{2}$ University of California, Davis, Land Air Water Resources Department.
} 


\section{INTRODUCTION}

griculture in Egypt is the highest water consumer sector, and
consumes around 64 billion $\mathrm{m}^{3}$ annually, which is more than
$80 \%$ of the total water resources. This amount of water is used to irrigate an average area of 8.5 million feddan, which represents about 9598\% of the total cultivated lands (CAPMAS, 2018). Under those circumstances, the irrigated agriculture in Egypt is facing serious challenges due to the imbalance between the water resources and demands, poor on-farm management, and the weak institutional and infrastructure frameworks. This situation of the sector struggle, is strongly affects the poorer farmers and decrease their production and income potential.

Improving agriculture and irrigation management needs to be based on more efficient and profitable use of water to produce more crops. Achieving this objective at the field level is suspended by many technical factors, for instance, the lack of accurate information and tools to estimate accurate crop-water requirements.

Generally, irrigation scheduling based on the reference evapotranspiration $\left(\mathrm{ET}_{\mathrm{o}}\right)$ data, is one of the widely-used methods to conduct an efficient onfarm irrigation management, while it depends on continual availability of $\mathrm{ET}_{\mathrm{o}}$ data. This method is based on estimating the "crop evapotranspiration", which is commonly estimated as the product of standardized $\mathrm{ET}_{\mathrm{o}}$, multiplied by a crop coefficient $(\mathrm{Kc})$ value. At the national level, one of the biggest deficiencies in water-use planning is a lack of continues, and updated data sets of evapotranspiration and accurate crop coefficient values. Although considerable information does exist, much of the literature is out-of-date because of changes in crops, management, and irrigation systems. As a result of this situation, there is a need to evaluate the different tools and methods of estimating evapotranspiration, and updating the crop coefficient values under the local conditions.

Allen et al. (2011) categorized three main approaches for ET measurements, which include methods related to the energy balance (e.g., Bowen ratio or residual of the energy balance), methods related to mass 
balance (e.g., lysimeters), and independent methods (e.g., latent heat flux from an eddy covariance (EC) system).

Eddy covariance (EC) method is one of the most common techniques for field-scale ET measurements (Anandakumar, 1999 and Simmons et al., 2007). The EC method involves simultaneous high-frequency measurements of vertical air velocity and scalar concentration, followed by computation of their covariance which represents the vertical flux of the measured scalar. Although the EC technique is reliable for research purposes, its applicability at the farm level is limited, mainly because of the high cost of the sensors, complexity of their operation, and the intensive data analysis. Therefore, in recent years, simpler techniques for direct ET measurements have been examined, such as "surface renewal" method.

The Surface Renewal (SR) method is based on the dynamics of sweeps and ejections of air parcels that occur near the canopy surface; it is assumed that this renewal mechanism is responsible for the exchange of sensible heat (and other constituents) between the crop and the atmosphere (Paw $\mathbf{U}$ et al., 1995). Using high frequency air temperature measurements, the renewal of sweeps and ejections is modeled as temperature ramps through a Structure Function analysis. Ramps amplitude and frequency enable estimating the sensible heat $(\mathrm{H})$ exchange between the canopy and the atmosphere (Snyder et al., 1996).

There are many studies on the use of the SR method for estimating evapotranspiration for different types of crops, including Snyder et al. (1996), Zapata and Martínez-Cob (2002), Castellví et al. (2006), Shapland et al. (2012), and Snyder et al. (2015).

Rice (Oryza sativa L.) is one of the important crops for food security in Egypt. The average total area of rice cultivated in Egypt is about 1.2 million feddan annually, which represent about $14 \%$ of the total cultivated area. The average production of rice in Egypt is about 3.9 ton/feddan. Rice is cultivated in Egypt in the summer season, from May to September. Despite its importance as profitable food and cash crop, rice is considered as one of the most inefficient water-use crop in the crop pattern of Egypt, because it is grown generally fully flooded, with an average water consumption higher than $4500 \mathrm{~m}^{3} /$ feddan per season. 
Allen et al. (1998) recommended the Kc values of rice as 1.05, 1.20, and $0.90-0.60$ for continuously flooded paddy rice during the initial-growth, midseason, and late-season stages, respectively. Careful water management is critical to improve water productivity of rice crop, that should be based on updated information about the actual water requirements of this crop under Egyptian conditions.

The aim of this study is to evaluate locally, the "Surface Renewal (SR)" method, as an energy balance direct method to estimate crop evapotranspiration (ETc), and upgrade crop coefficients $(\mathrm{Kc})$ of rice crop in Egypt.

\section{MATERIALS AND METHODS}

\section{Theoretical bases of SR method:}

The "Surface Renewal (SR)" method is based on the dynamics of the turbulent boundary layer above the canopy which was modeled by the mixing layer analogy (Raupach et al., 1996). Among other characteristics of this layer, sweeps and ejections of air parcels from the canopy, driven by wind shear and/or temperature changes, have been identified. The SR technique is based on modeling these ejections and sweeps through simple temperature measurements as a way of estimating the sensible heat exchange between the canopy and the atmosphere (Castellvi et al., 2006). The surface renewal (SR) method is used to estimate the sensible heat flux density $[\mathrm{H}]$ and the latent heat flux density [LE] as the residual of the energy balance (REB) using the energy balance equation:

$$
\mathrm{LE}=\mathrm{Rn}-\mathrm{G}-\mathrm{H}
$$

In which $[\mathrm{Rn}]$ is the "net radiation" and $[\mathrm{G}]$ is the "ground heat flux density at the soil surface". The main advantage of the SR method is its simple application: it only uses high-frequency temperature measurements from fine wire thermocouples to determine an average change in temperature with time within the air above a canopy, and the volumetric heat content of the air to estimate $\mathrm{H}$. The SR method is based on conservation of energy with a strong theoretical basis.

In fact, the SR H is calculated from the average heating of the air parcel and the number of times the air parcel is renewed at the surface over 30min intervals as follows: 


$$
H_{S R}=\alpha H^{\prime}=\alpha\left[z \rho C_{p}\left(\frac{a}{t_{r}}\right)\right]
$$

where $\alpha=$ calibration factor; $\mathrm{z}=$ measurement height; $\rho=$ air density ( $\mathrm{g}$ $\left.\mathrm{m}^{-3}\right) ; \mathrm{C}_{\mathrm{p}}=$ specific heat of air at constant pressure $\left(\mathrm{J} \mathrm{g}^{-1} \mathrm{~K}^{-1}\right)$; and $\mathrm{a}=$ average ramp amplitude $(\mathrm{K})$, which corresponds to the temperature enhancement of the air parcel. $\left[\mathrm{t}_{\mathrm{r}}\right]$ is the mean air parcel renewal time over the sampling period (Paw $U$ et al. 1995). The ramp amplitude [a] and duration $\left[\mathrm{t}_{\mathrm{r}}\right]$ were determined using the Van Atta ramp model (Van Atta 1977), which uses half-hour means of the second, third, and fifth moments of the air temperature structure function [Eq. (2)]

$$
S^{n}(r)=\frac{1}{m-j} \sum_{i=1+j}^{m}\left(T_{i}-T_{i-j}\right)^{n}
$$

where $\mathrm{m}=$ number of data points in the half-hour interval measured at frequency (f); $\mathrm{n}=$ order of the structure function; $\mathrm{j}=$ sample lag between data points corresponding to a time lag $(\mathrm{r} j / \mathrm{f})$; and $\mathrm{T}_{\mathrm{i}}=\mathrm{ith}$ temperature sample (K). In this research, the second, third, and fifth moments were calculated and recorded for both $r=0.25 \mathrm{~s}$ and $\mathrm{r}=0.50 \mathrm{~s}$.

After determining the latent heat flux density, the ETc-SR $\left[\mathrm{mm} \cdot \mathrm{d}^{-1}\right]$ was calculated by dividing the $\mathrm{LE}\left[\mathrm{MJ} \cdot \mathrm{m}^{-2} \cdot \mathrm{d}^{-1}\right]$ by $\mathrm{L}=2.45 \mathrm{MJ} \cdot \mathrm{kg}^{-1}$ to obtain the ETc in $\mathrm{kg} \cdot \mathrm{m}^{-2} \cdot \mathrm{d}^{-1}$, which is equivalent to $\mathrm{mm} \cdot \mathrm{d}^{-1}$.

More details on the SR method may be found in Paw U et al. (1995), Snyder et al. (1996), Spano et al. (1997), and Shapland et al. (2012).

\section{The field assessment:}

SR station was installed in the "agricultural production sector" farm $\left(30.39^{\circ} \mathrm{N}, 31.25^{\circ} \mathrm{E}, 27 \mathrm{~m}\right)$ in Moshtouhor, at Kaliobia governorate. The station recorded half- hourly data, using Campbell Scientific CR3000 data logger. High-frequency temperature data for the SR estimates of the sensible heat $[\mathrm{H}]$ exchange between the canopy and the atmosphere was measured with a 76.2- $\mu \mathrm{m}$ diameter Chromel-Constantan thermocouple model FW3 sensor. The fine-wire thermocouple data and sonic anemometer data were collected at a $10 \mathrm{~Hz}$ sampling rate, and the other variables were sampled once per minute. 
The station had two soil heat flux [G] groups, consisted of one HFT3 heat flux plate inserted at $0.15 \mathrm{~m}$ depth below the soil surface, and two TCAV soil thermistor at $0.05 \mathrm{~m}$ depths above and under the heat flux plates. The first soil group was installed under the plants row, and the other group was inserted between the plants rows.

The soil texture of the experiment location was clay, and Table (1) shows the physical properties of soil, and soil-water relationships of this location.

Rice crop, of "Giza 179" cultivar, was cultivated by direct seedling in a field area of 15 feddan, at 27 May 2015. The field was flooded by water at depths 7 to $10 \mathrm{~cm}$, and the water was drained and recycled every three days. The irrigation was cut-off and water totally drained at 22 days before the harvesting, which was carried out at 27 Sept 2015.

For Upgrading Kc values, the standard $\mathrm{ET}_{\mathrm{o}}$ data was estimated by using FAO-Penman equation, from the collected data weather by Dacom $\mathrm{ET}_{\mathrm{o}}$ stations installed in the same location of the experiments.

Table (1): Physical properties of soil, and soil-water relationships at Moshtouhor- Qalubia, Egypt.

\begin{tabular}{|c|c|c|c|c|c|c|c|}
\hline \multirow{3}{*}{ Depth } & \multicolumn{4}{|c|}{ Physical properties } & \multicolumn{3}{c|}{ soil-water relationships } \\
\cline { 2 - 8 } & $\begin{array}{c}\text { Sand } \\
{[\%]}\end{array}$ & $\begin{array}{c}\text { Silt } \\
{[\%]}\end{array}$ & $\begin{array}{c}\text { Clay } \\
{[\%]}\end{array}$ & $\begin{array}{c}\text { Textural } \\
\text { class }\end{array}$ & $\begin{array}{c}\text { F.C. } \\
{[\%]}\end{array}$ & $\begin{array}{c}\text { P.W.P } \\
{[\%]}\end{array}$ & $\begin{array}{c}\text { B.D } \\
{\left[\mathrm{g} / \mathrm{cm}^{3}\right]}\end{array}$ \\
\hline $0-40$ & 22.23 & 27.92 & 49.85 & Clay & 33.50 & 16.00 & 1.10 \\
\hline $40-70$ & 23.19 & 28.19 & 48.62 & Clay & 38.50 & 18.50 & 1.15 \\
\hline
\end{tabular}

F.C.: Field capacity; P.W.P: Permanent wilting point; B.D: Bulk Density

Applying SR method to calculate the rice crop ETc, were carried on through a special program developed by Microsoft Excel application, to conduct flux data processing using a modified version of the Van Atta (1977) structure function, which is described in Shapland et al. (2012).

For the upgrading of the crop coefficient $(\mathrm{Kc})$ curves, the standard KcFAO curve recommended by Allen et al. (1998) for flooded paddy rice was used, and compared with the actual Kc-SR curve estimated from dividing the actual ETc-SR by the $\mathrm{ET}_{\mathrm{o}}$ 
Root mean squared error (RMSE) were used as statistical factors to evaluate the goodness of fit between simulated and measured values of the analyzed data, using the following equations (Jacovides and Kontoyiannis, 1995):

$$
\begin{aligned}
& R M S E=\sqrt{\frac{1}{n} \sum_{i=1}^{n}\left(E T c_{F A O}-E T c_{S R}\right)} \\
& R M S E=\sqrt{\frac{1}{n} \sum_{i=1}^{n}\left(K c_{F A O}-K c_{S R}\right)}
\end{aligned}
$$

Where $[\mathrm{n}]$ represents the number of the observations of the parameters. In general, the simulation is better when the RMSE value is closer to zero

\section{RESULTS AND DISCUSSION}

Figure (1) shows the mean daily patterns of the energy balance components during the cultivation season of rice. In general, flooded rice paddies, with minimal vegetation, had lower albedo, and the albedo increased as the rice plants grew and covered the surface. At the initial stage of the rice planting season, sensible heat flux density and net radiation was consistently high because the small coverage of plant canopy above the water surface. Sensible heat flux and net radiation decreased during the season as a result of the increase in the canopy size over the water surface, and the cooling effect of the plants. As a result of the overall energy balance, the water energy and temperature was higher at the initial stage of the planting season, and it continue to decrees throughout the season as a result of the plant canopy shading the water from solar radiation.

Based on the observed energy balance, the actual daily ETc-SR was estimated by using the SR method, and compared with the ETc-FAO daily (estimated from the multiplying the $\mathrm{ET}_{\mathrm{o}}$ values by the standard smoothed Kc-FAO). Figure (2) shows the daily values of the ETc-SR, $\mathrm{ETc}-\mathrm{FAO}$ and $\mathrm{ET}_{\mathrm{o}}$. As noticed from the figure the values of $\mathrm{ET}_{\mathrm{o}}$ and ETcFAO show some high fluctuations for some days, as a result of using low 
resolution wind speed data from the standard $\mathrm{ET}_{\mathrm{o}}$ station. For both ETcSR and ETc-FAO, the average daily value was $5.3 \mathrm{~mm} /$ day along the season. Whereas the daily value of the initial stage was 5.1 and 4.9 $\mathrm{mm}$ /day for ETc-SR and ETc-FAO, respectively. This average increased to be 5.5 and $5.7 \mathrm{~mm} /$ day for the mid-season stage ETc-SR and ETcFAO, respectively. And decreased to be 4.9 and $5.0 \mathrm{~mm} /$ day for ETc-SR and ETc-FAO, respectively.

The determined overall RMSE between the ETc-SR and the ETc-FAO was $0.92 \mathrm{~mm} /$ day. The RMSE between the ETc-SR and the ETc-FAO values changed during the different growth stages, that it was 1.27 $\mathrm{mm} /$ day at the initial-season stage as a result of the high energy fluxes from the water surface of the flooded paddy rice. The RMSE between the ETc-SR and the ETc-FAO values decreased at the mid-season stage to $0.80 \mathrm{~mm} /$ day, and reached to the minimum level to $0.48 \mathrm{~mm} /$ day at the late-season stage.

Figure (3) shows the cumulative values of the ETc-SR, ETc-FAO and $\mathrm{ET}_{\mathrm{o}}$. The total estimated ETc-SR was $527 \mathrm{~mm} /$ season, whereas the total $\mathrm{ET}_{\mathrm{o}}$ and ETc-FAO were 466 and $533 \mathrm{~mm} /$ season.

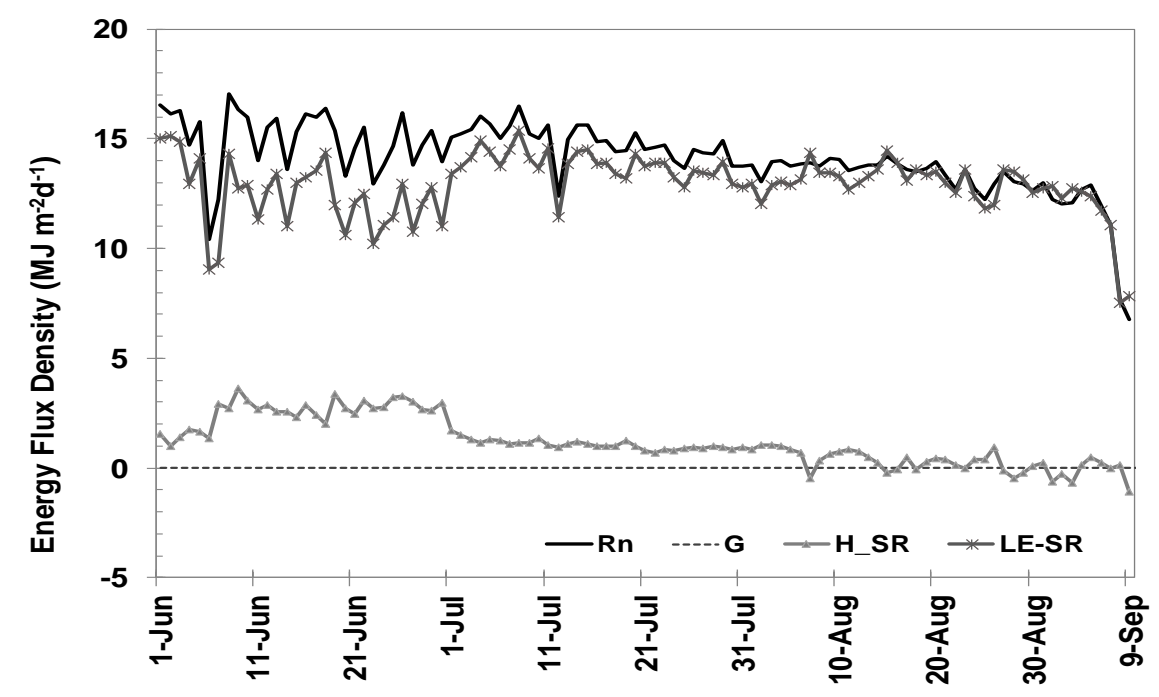

Fig. (1): The daily presentation of the energy balance main fluxes, of net radiation $(R n)$ and sensible heat $(H)$, latent heat $(L E)$, and soil heat flux $(G)$ density measured during the experiments of rice 


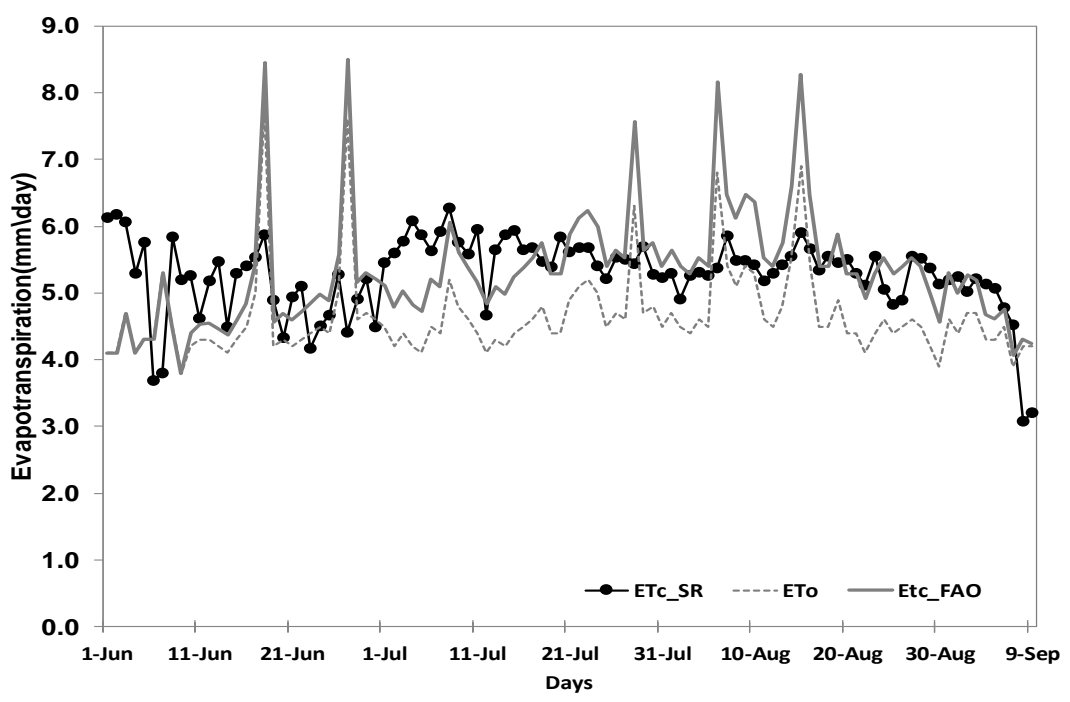

Fig. (2): The daily ETc-SR, ETc-FAO and $\mathrm{ET}_{\mathrm{o}}$ of rice crop.

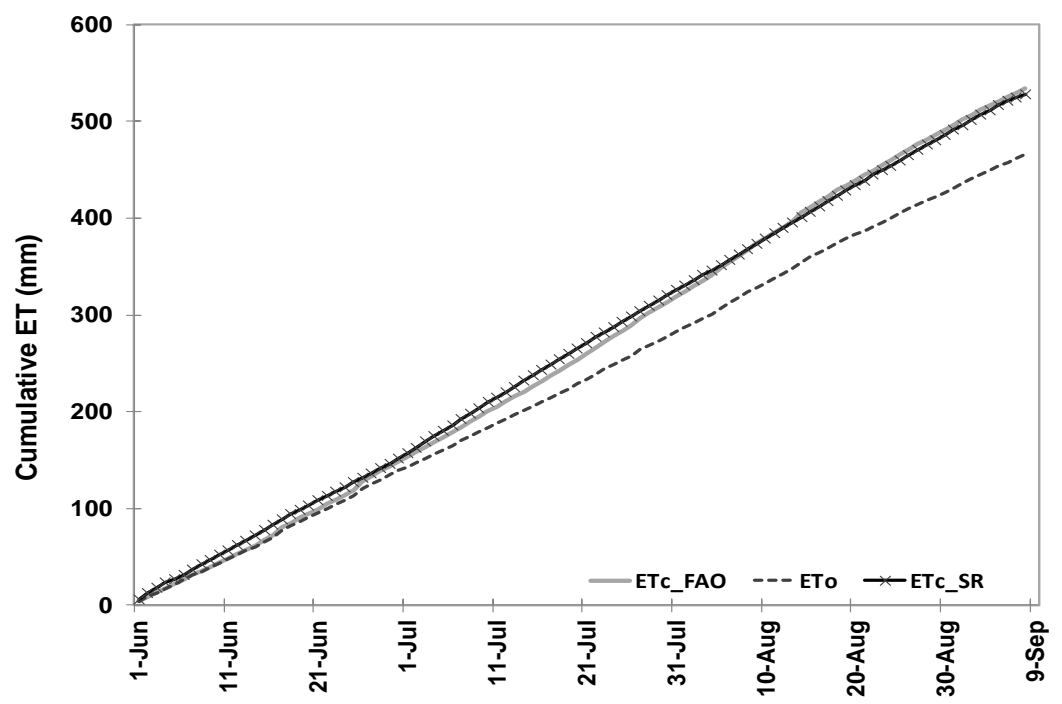

Fig. (3): Cumulative values of ETc-SR, ETc-FAO and ET ${ }_{0}$ during the growing season of rice crop.

Figure (4) shows the difference the daily actual Kc-SR values vs. the smoothed curve of Kc-FAO recommended by FAO. The average value of Kc-SR was 1.17, 1.13 and 1.14 at the initial-season, mid-season and late season stages, respectively. The overall RMSE between the Kc-SR and the Kc-FAO values was 0.11 . The RMSE was 0.17 , which at its highest 
value at the initial-season stage. The RMSE decreased throughout the season to be 0.10 at the mid-season, and 0.03 at the late-season stage.

The estimated Kc values from SR are dynamic variables affected by the cultivars of the crop, the on-farm management practices, and the environmental conditions. Considering this type of variability in irrigation scheduling could improve the water productivity at farm level by significant amounts, which have a positive impact on water-use optimization in agriculture.

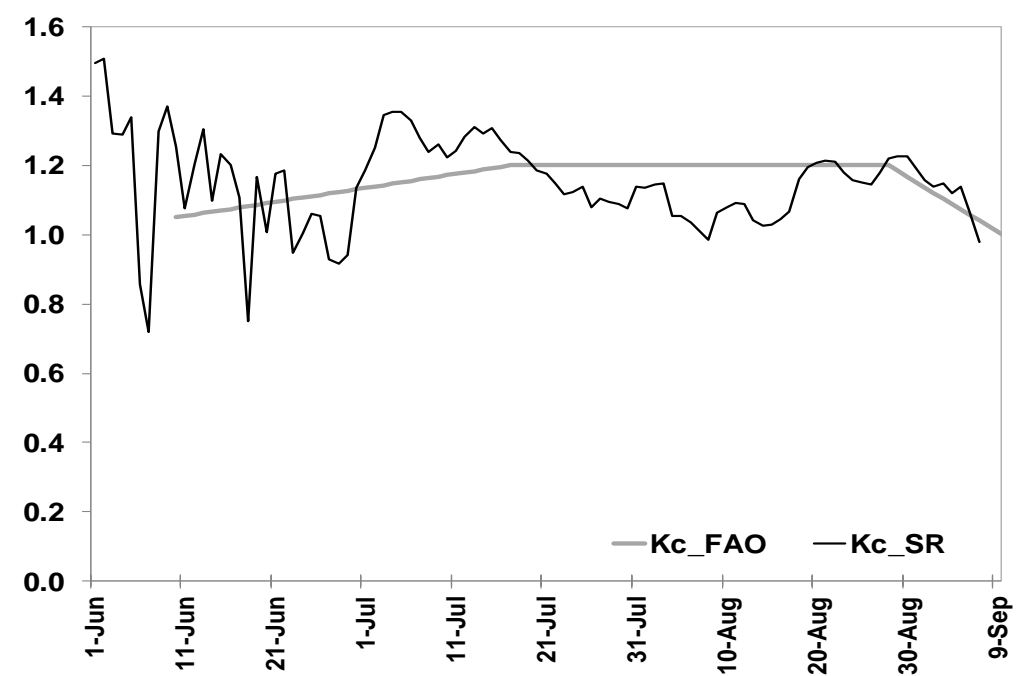

Fig. (4): The daily Kc-SR and Kc-FAO of rice crop

\section{CONCLUSION}

In conclusion, SR method as a direct method for ETc estimation, operates close to the canopy, thus minimizing fetch requirements, which make it a useful and sensitive micrometeorological method. The combination of the SR procedure and the simplified surface energy balance equation appears to be an affordable alternative to be considered for estimating water use in agriculture. Unless, the SR method still need several evaluations, calibration work, in order to be used significantly to upgrade the Kc value for the local crop cultivars in Egypt. The estimated Kc values from SR are dynamic variables affected by the cultivars of the crop, the on-farm management practices, and the environmental conditions. Considering this type of variability in irrigation scheduling could improve the water 
productivity at farm level by significant amounts, which have a positive impact on water-use optimization in agriculture.

Further work still required to calibrate SR method to be applied for different crops, at different agroecozones, in the way which allow upgrading the Kc values for the main crops Egypt to match the actual specifications of the Egyptian cultivars.

\section{AKNOWELDGEMENT}

The case study introduced in this work was among the activities of The project "New Approach for Measuring Crop Evapotranspiration and updating Crop Coefficients in Egypt", through years 2012-2017. The project funded by the US-Egypt collaborative program- STDF, and implemented by Agricultural Engineering Research Institute (AEnRI)ARC.

\section{REFERENCES}

Allen, R. G., Pereira, L. S., Howell, T. A., and Jensen, M. E. (2011). Evapotranspiration information reporting. I: Factors governing measurement accuracy. Agric. Water Manage., 98(6), 899-920.

Allen, R.G., Pereira, L.S., Raes, D., Smith, M. (1998). Crop evapotranspiration: guidelines for computing crop water requirements. In: FAO Irrigation and Drainage Paper No. 56. FAO, Rome, Italy, 300 pp.

Anandakumar, K. (1999). Sensible heat flux over a wheat canopy: optical scintillometer measurements and surface renewal analysis estimations. Agricultural and Forest Meteorology, 96, $145 \mathrm{e} 156$.

CAPMAS (2018). Statistical yearbook. Central Agency for Public Mobilization and Statistics. Egypt.

Castellví, F., Snyder, R. L., Baldocchi, D. D., and Martínez-Cob, A. (2006). "A comparison of new and existing equations for estimating sensible heat flux using surface renewal and similarity concepts." Water Resour. Res., 42(8), 1-18. 
Jacovides, C.P, Kontoyiannis, H. (1995). Statistical procedures for the evaluation of evapotranspiration computing models. Agricultural Water Management 27(3-4):365-371.

Montazar, A; Rejmanek, H.; Tindula, G.; Little, C.; Shapland, T.; Anderson, F.; Inglese, G.; Mutters, R.; Linquist, B.; Greer, C. A.; Hill, J.; and Snyder, R. L. (2016) Crop Coefficient Curve for Paddy Rice from Residual Energy Balance Calculations. Journal of Irrigation and Drainage Engineering. Journal of Irrigation and Drainage Engineering, DOI: 10.1061/(ASCE)IR.19434774.0001117.

Paw U, K. T., Qiu, J., Su, H. B., Watanabe, T., and Brunet, Y. (1995). "Surface renewal analysis: A new method to obtain scalar fluxes without velocity data.” Agric. For. Meteorol., 74(1-2), 119-137.

Raupach, M.R., Finnigan, J.J., Brunet, Y. (1996). Coherent eddies and turbulence in vegetation canopies: the mixing-layer analogy. Bound-Layer Meteorol. 78, 351-382.

Shapland, T. M., Snyder, R. L., Smart, D. R., and Williams, L. E. (2012). "Estimation of actual evapotranspiration in wine grape vineyards located on hillside terrain using surface renewal analysis." Irrig. Sci., 30(6), 471-484.

Simmons, L. J., Wang, J., Sammis, T. W., \& Miller, D. R. (2007). An evaluation of two inexpensive energy-balance techniques for measuring water use in flood-irrigated pecans (Carya illinoinensis). Agricultural Water Management, 88, 181e191

Snyder, R. L., Spano, D., and Paw U, K. T. (1996). "Surface Renewal analysis for sensible and latent heat flux density." Boundary Layer Meteorol., 77(3-4), 249-266.

Snyder, R. L., Pedras, C., Montazar, A., Henry, J. M., and Ackley, D. A. (2015). "Advances in ET-based landscape irrigation management." Agric. Water Manage., 147(1), 187-197. 
Van Atta, C. W. (1977). "Effect of coherent structures on structure functions of temperature in the atmospheric boundary layer." Arch. Mech., 29, 161-171.

Zapata, N., and Martínez-Cob, A. (2002). "Evaluation of the surface renewal method to estimate wheat evapotranspiration." Agric. Water Manage., 55(2), 141-157.

\section{الملخص العربي}

طريقة جديدة لتقدير الإستهلاك المائى و تعديل معامل المحصول للأرز فى مصر بطريقة السطح المتجد المبد

أمل أبو المجد'، سمرمحمد الطاهر '،ريتشارد سينايدر'، حازم سيد مهاود' و جمال حسن السيد' يتطلب تطوير إدارة الرى نو افر معلومات و أدوات دقيقة لتقدير الاحتياجات المائية للححاصيل. و

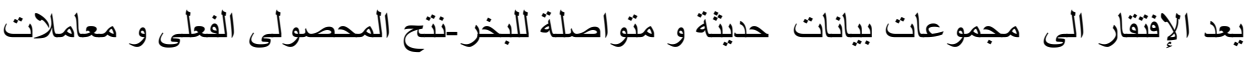

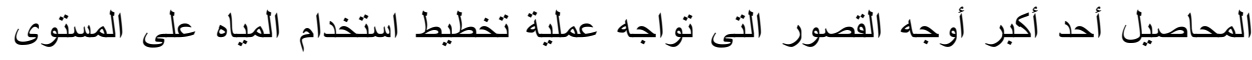

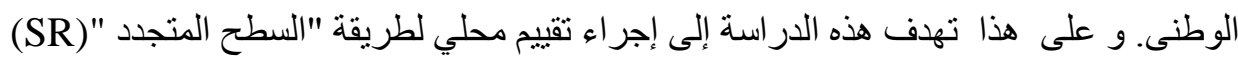

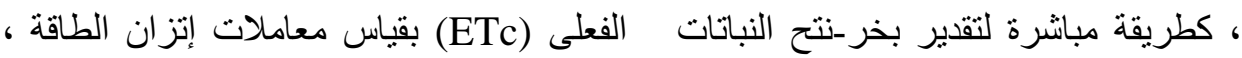

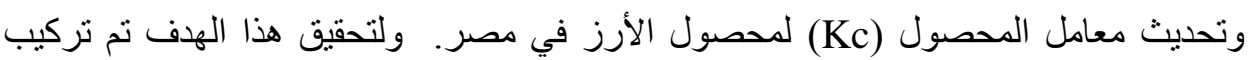

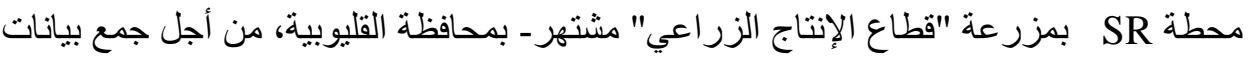

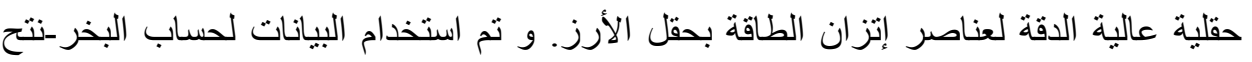

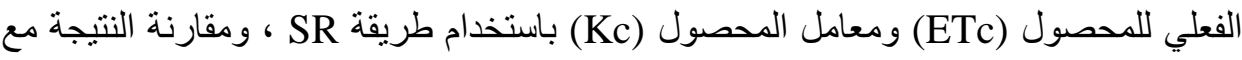

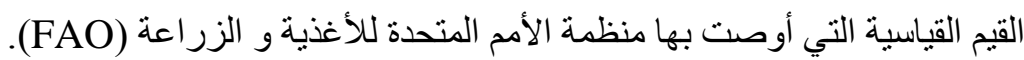

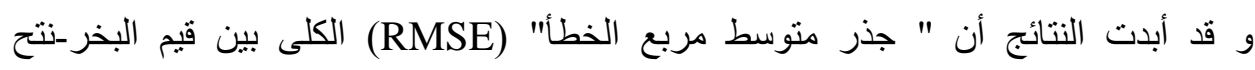

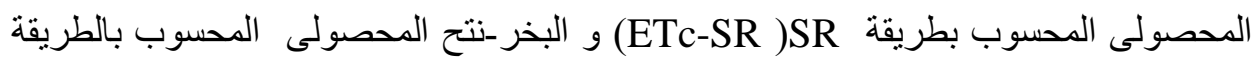

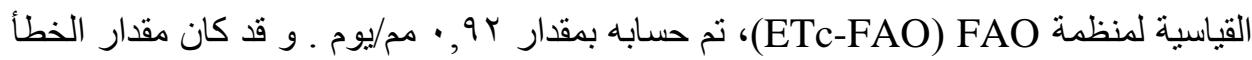

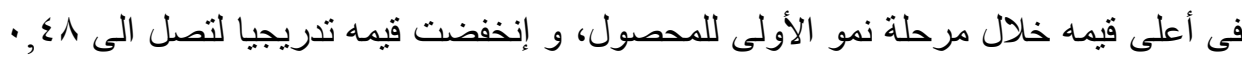

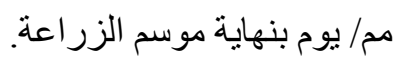

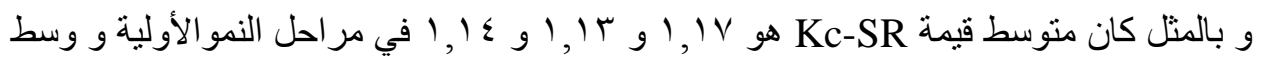

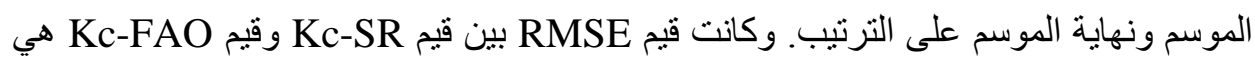

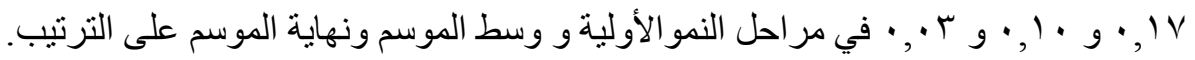

$$
\text { 'معهد بحوث الهندسة الزراعية، مركز البحوث الزراعية، مصر. }
$$

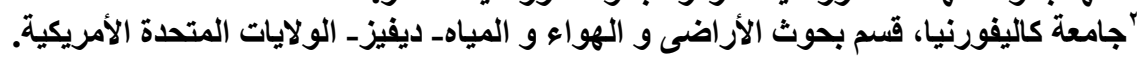


وبناء على النتائج، يتضح أن الجمع بين استخدام طريقة SR و و التعبير المبسط لمعادلة إتزان

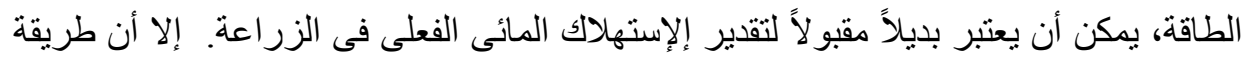
SR لتحديث قيم Kc للأصناف المحلية للمحاصيل الهامة في مصر. 